\title{
0548. Effects of sedation and muscle paralysis on inflammation during mechanical ventilation
}

\author{
LG Ayala ${ }^{1}$, M Abreu$^{1 *}$, M Avila ${ }^{2}$, BC Bergamini', AC Neto ${ }^{1}$, WA Zin², A Giannella Neto ${ }^{1}$, AR Carvalho ${ }^{1,2}$ \\ From ESICM LIVES 2014 \\ Barcelona, Spain. 27 September - 1 October 2014
}

\section{Introduction}

A significant reduction in mortality was observed in severe ARDS patients when neuromuscular blockage (NMB) was used in the acute phase (Papazian L. et al, 2010).

\section{Objectives}

We aim to evaluate pro- and anti-inflammatory markers immediately after two hours ventilation in lung-injured rats with different sedation protocols.

\section{Methods}

Thirty male Wistar rats were divided into five groups (6 animals each): low sedation, high sedation (with or without NMB) and a healthy, non-ventilated control group. Animals were anesthetized with 2.8 or $1.4 \% \mathrm{vol}$ isoflurane and 2.5 or $0.5 \mathrm{mg} / \mathrm{kg}$ midazolam in high and low sedation groups, respectively; and $10 \mathrm{mg} / \mathrm{kg}+10 \mathrm{mg} / \mathrm{kg} / \mathrm{h}$ atracurium in NMB group. After intubation and stabilization period (baseline settings: $\mathrm{VT}=8 \mathrm{~mL} / \mathrm{kg}, \mathrm{FR}=70 \mathrm{rpm}$, $\mathrm{FiO} 2=50 \%, \mathrm{PEEP}=3, \mathrm{I}: \mathrm{E}=1: 2$ ), lung injury was induced by intratracheal injection of LPS $(15 \mathrm{mg} / \mathrm{kg})+$ ventilation induced lung injury $\left(2.5 \mathrm{xVT}, \mathrm{FR}=32, \mathrm{PEEP}=10 \mathrm{cmH}_{2} \mathrm{O}\right.$ for 45s) (Dixon et al, 2009). Thereafter animals were ventilated for 2 hours with baseline settings. Airway (Paw), esophagic (Peso) were continuously recorded $(200 \mathrm{~Hz}$ sampling frequency). The mean power of Peso was then calculated, by means of the spectral density estimation (Welch's periodograms, 400 samples window, 50\% overlap). At the end of ventilation, mean arterial pressure (MAP) and gas analysis were evaluated in all ventilated groups. Lungs were extracted for cytokines (IL-6, IL-10) measurement. Euthanasia was performed by exsanguination associated to isoflurane overdose. Data were

${ }^{1}$ Federal University of Rio de Janeiro, Laboratory of Pulmonary Engineering, Rio de Janeiro, Brazil

Full list of author information is available at the end of the article compared with Shapiro-Wilk, ANOVA and Bonferroni post-hoc tests, $\mathrm{p} \leq 0.05$.

\section{Results}

No differences in mean MAP and heart rate were observed. $\mathrm{PaO}_{2} / \mathrm{FiO}_{2}$ and $\mathrm{PCO}_{2}$ were higher in nonparalized groups compared to paralyzed groups $(\mathrm{p}=0.01)$. Peak and mean Paw were significantly lower $(\mathrm{p} \leq 0.01)$ whereas the mean power of Peso was higher $(p=0.004)$ in the low sedation without NMB. IL-6 concentration was also significantly lower in this group $(\mathrm{p}<$ $0.001)$ and presented a negative correlation $(r=-0.59$, $\mathrm{R}^{2}=0.34$ and $\mathrm{p}=0.002$ ) with Mean power of Peso. Furthermore, IL-10 concentration was higher in the low sedation without NMB compared to the others $(\mathrm{p}=0.002)$ and also correlates with the mean power of Peso $\left(r=0.60, R^{2}=0.36\right.$ and $\left.P=0.002\right)$.

\section{Conclusions}

Animals with a superficial sedation scheme in absence NMB might have more recruited lungs (lower Ppeak and Pmean), less inflammation and higher anti-inflammatory markers. The long-term consequences must be further evaluated.

\section{Grant acknowledgment}

This work was supported by CAPES, CNPq and FAPERJ.

\section{Authors' details}

${ }^{1}$ Federal University of Rio de Janeiro, Laboratory of Pulmonary Engineering, Rio de Janeiro, Brazil. ${ }^{2}$ Federal University of Rio de Janeiro, Carlos Chagas Filho Institute of Biophysics, Rio de Janeiro, Brazil.

\section{Published: 26 September 2014}

\section{References \\ 1. Papazian L, Forel J-M, Gacouin A, et al: Neuromuscular blockers in early acute respiratory distress syndrome. $N$ Engl I Med 2010, 363:1107-16.}

\section{SpringerOpen ${ }^{\circ}$}

(0) 2014 Ayala et al; licensee Springer. This is an Open Access article distributed under the terms of the Creative Commons Attribution License (http://creativecommons.org/licenses/by/2.0), which permits unrestricted use, distribution, and reproduction in any medium, provided the original work is properly cited. 
2. Dixon D, De Smet H, Berstena AD: Lung mechanics are both dose and tidal volume dependant in LPS-induced lung injury. Resp Physiol Neurobiol 2009, 167:333-340.

doi:10.1186/2197-425X-2-S1-P32

Cite this article as: Ayala et al.: 0548. Effects of sedation and muscle paralysis on inflammation during mechanical ventilation. Intensive Care Medicine Experimental 2014 2(Suppl 1):P32.

\section{Submit your manuscript to a SpringerOpen ${ }^{\mathcal{O}}$ journal and benefit from:}

- Convenient online submission

- Rigorous peer review

- Immediate publication on acceptance

- Open access: articles freely available online

- High visibility within the field

- Retaining the copyright to your article

Submit your next manuscript at $\gg$ springeropen.com 